\title{
An overview of the commercial determinants of health
}

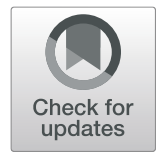

Melissa Mialon(D)

\begin{abstract}
Background: Different terms are described in the literature that refer to commercial determinants as drivers of illhealth. The aim of the present review was to provide an overview of the commercial determinants of health, through a review of the literature on this subject. The review was conducted in December 2019 and updated in February 2020. Searches were conducted from peer-reviewed scientific articles, commentaries, books, and books chapters, with no restriction in their publication dates and languages.

Main body: The commercial determinants of health cover three areas. First, they relate to unhealthy commodities that are contributing to ill-health. Secondly, they include business, market and political practices that are harmful to health and used to sell these commodities and secure a favourable policy environment. Finally, they include the global drivers of ill-health, such as market-driven economies and globalisation, that have facilitated the use of such harmful practices.

Short conclusion: The discussion on the commercial determinants of health offers a unique opportunity to shift the dominant paradigm in public health, where individual behaviours are considered to be driven by inadequate environments. III-health, damages to the environment, and health and social inequalities, might be better understood through a commercial determinant lens.
\end{abstract}

Keywords: Commercial determinants of health, Corporate political activity, Industry, Public health, Noncommunicable diseases

\section{Background}

There is an emergent discussion, at the international level, on the commercial determinants as drivers of illhealth [1-3], amongst other social determinants [4]. Different terms are described in the literature to refer to these determinants. In 2013, Millar introduced the term 'corporate determinants of health' to refer to both the positive and negative influence that corporations have on population health, an idea further developed by other academics, such as Rochford et al. [5, 6]. Millar argued that companies generate employment and are a source of revenue through taxes, thus supporting the economic development of countries [5]. The author refers to the

Correspondence: melissa_mialon@hotmail.fr

School of Public Health, University of São Paulo, São Paulo, Brazil triple bottom line of corporations: people, planet and profits [5]. Some scholars have, however, argued that corporations' search for profit is in direct contradiction with public health goals [7]. In his work, Millar acknowledges that, in some cases, corporations have a negative impact on health and the environment [5]. The term 'commercial determinants of health' $(\mathrm{CDoH})$ was first introduced in the literature in 2013 by West and Marteau [8]. The term became popular after 2016 when used by Kickbush et al. define $\mathrm{CDoH}$ as "strategies and approaches used by the private sector to promote products and choices that are detrimental to health" [1]. Other terms have also been used in the literature: the "commercial determinants of ill health' [9]; the 'commercial drivers of ill-health' [10]; the 'commercial determinants of non-communicable diseases' (NCDs) [10]; the 
'commercial drivers of NCDs' [1]. The World Obesity Federation, a global professional association, uses the term 'commercial determinants of obesity' [11].

Some have described the development of conceptualizing $\mathrm{CDoH}$, as a separate object of inquiry, over time, and proposed potential solutions to address one of the most pressing challenges in public health [2]. Others have developed models to understand [1] and study $\mathrm{CDoH}[12,13]$. Maani et al. recently noted that there is, however, a lack of clarity on what the term $\mathrm{CDoH}$ means [14]. In another publication, Maani et al. noted that commercial determinants remain largely ignored in existing frameworks on the social determinants of health [4]. The aim of the present review was to provide an overview of $\mathrm{CDoH}$ and feel the gap on the understanding of $\mathrm{CDoH}$.

\section{Methods}

The review was conducted in December 2019 and updated in February 2020. The author identified relevant scientific literature, including peer-reviewed articles, commentaries, books, and books chapters with no restriction in their publication dates and languages. Searches were initially conducted using the bibliography section in Kickbush et al.'s article [1] for publications that focused on $\mathrm{CDoH}$, industrial epidemic, or corporate political activity (CPA). Forward (i.e., citations referring to this initial set of documents, using Scopus) and backward searches (i.e., references section of these documents) were then conducted using these publications. Additional documents discussing specific aspects of $\mathrm{CDoH}$ were then identified through snowball searches. All documents identified for this review were managed with F1000 Workspace.

The term 'corporate', used for example by Millar, usually refers to an organisation, while the term 'commercial' relates to activities intended to make a profit. The present review used the term 'commercial determinants of health' and was guided by the above definition by Kickbush et al. For the present review, the term 'corporations' refers to the individuals and organisations involved in the production, distribution and marketing of commodities: manufacturers, wholesalers, retailers, distributors, service providers, and producers of raw material, as well as organisations acting on their behalf, such as trade associations, public relations firms, philanthropic organisations, and research institutions. Freudenberg described these individuals and organisations as the 'corporate consumption complex' [15].

Kickbush et al.'s framework was used to structure the present review. This framework first presents the outcomes resulting from $\mathrm{CDoH}$, including ill-health [1]. The authors explain that different channels, such as marketing and lobbying, described in this review as 'corporate practices harmful to health', are driving these outcomes [1]. Finally, Kickbush et al. suggest that these channels are the products of macro-drivers, such as the internationalisation of trade and capital, which are referred in this review as 'global drivers of ill-health' [1]. In addition to these aspects of $\mathrm{CDoH}$, the present review discusses 'unhealthy commodities', an aspect of $\mathrm{CDoH}$ not directly addressed in Kickbush et al.'s framework.

\section{The commercial determinants of health}

Most of the scientific literature on $\mathrm{CDoH}$, as a separate object of inquiry, was published in the past decade and in English, primarily, in high income countries.

\section{Corporations, unhealthy commodities and the industrial epidemic}

NCDs, including cardiovascular diseases and cancers, are the leading cause of mortality globally and responsible for $71 \%$ of all deaths [16]. Harmful alcohol drinking, tobacco use, physical inactivity, and the consumption of unhealthy diets, particularly of ultra-processed food products, are the main risks factors for developing NCDs [17]. Other commodities, such as certain chemicals and pesticides, also have a negative impact during their production and use, notably on workers, the health of communities, and the environment $[18,19]$. While they might be beneficial, under certain circumstances, the use of motor vehicles [20] and drugs [21], amongst other products, also poses a threat to individuals. These products are collectively described by Stuckler et al. as 'unhealthy commodities' [22]. Freudenberg noted that, beyond NCDs, the consumption of unhealthy commodities also leads to a rise in air pollution; a lack of access to essential medicines, to clean water, and to healthy foods; and an increase in the exposure to motor vehicle crashes and gun violence [15]. In 2007, Jahiel and Babor used the concept of an 'industrial epidemic', where corporations are described as 'vectors of diseases'; unhealthy commodities are the agents of these diseases; and individuals the hosts [23]. Jahiel also defined the 'corporation-induced diseases' resulting from the industrial epidemic as "diseases of consumers, workers, or community residents who have been exposed to disease agents contained in corporate products" and called for the epidemiological surveillance of these diseases [24]. Collin and Hill further explained that the industrial epidemic is a structural driver of health inequalities [25]. While interventions to prevent and control NCDs and other diseases often target behavioural risks factors, ultimately, it is the exposure to these unhealthy commodities that pose a risk to health $[22,26]$.

In the literature, the discussion on the impact of corporate activity on public health often focuses on the alcohol, tobacco, and food industries, also known as Big Alcohol [27], Big Tobacco [28], and Big Food [22, 29, 30]. As 
described above, other industries also have a negative impact on health: the automobile industry $[20,31]$, the pharmaceutical industry [21], and the mining sector [18], amongst others [32]. In the scientific literature, these corporations are referred to as 'vectors of diseases' (or 'corporate disease vectors') [23, 33, 34]; 'industries producing unhealthy commodities' (and its variant, 'unhealthy commodity industries') [22, 26]; 'dangerous consumption industries' [35]; and 'health harming industries' [36].

\section{Corporations and practices harmful to health}

Corporations seek to make a profit from their commodities. They use 'business practices' to run their activities; and 'market practices' to develop, produce and sell their commodities [34, 37]. Corporations also use political practices to secure a favourable policy environment [34, 37].

In 2018, Madureira Lima and Galea proposed a framework for understanding the broad impacts that corporate practices have on health [12]. The authors explained that the power of corporations is exerted through five vehicles: political environment; preference shaping; the knowledge environment; the legal environment; and the extra legal environment [12]. The authors later used their framework to evaluate the extent to which corporations have penetrated the "social, political and cultural fabric of a country", also called 'corporate permeation' [38]. In a recent analysis, the authors quantified the corporate permeation in 148 countries [38]. Their evaluation served to better understand the reasons behind the level of consumption of unhealthy commodities, and the existence (or not) of policies to address this consumption in countries [38]. The authors found different levels of corporate permeation across the globe [38].

Baum et al. developed another framework, with a focus on transnationals specifically, called the 'corporate health impact assessment' [13]. Their model discusses the political, economic and regulatory environments; the structure, practices and products of corporations; and the health and equity impacts of the activities of corporations [13]. The authors later applied their model for an evaluation of the activities of a fast-food restaurant and a mining company $[39,40]$. Their findings showed that corporations could have a positive impact when providing employment in communities, for example, but this could be undermined by the precariousness of such employment, and the negative impacts of the company's activities on the environment and health $[39,40]$. It has been noted that the Baum et al. model, however, fails to address some corporate practices, such as the influence of businesses on science and social norms [12].

For the present review, a distinction was made between the business and the market practices of corporations. The former focuses on the practices that corporations use to run their activities, while the latter focuses on the commodities themselves. Some corporations may market commodities that are considered healthy, such as bananas, but could use business practices that are harmful to health, such as avoiding paying taxes or treating their workers poorly, for example.

Specifically, the business practices of corporations include, amongst other things, the control of the supply chain and market concentration (through mergers and acquisitions for example); labour practices; taxation payments and profits shifting; and the privatisation of utilities $[1,13,15,41]$. In 2018, Wiist explained that corporate tax avoidance, for example, leads to a shortage of public tax revenue that could be directed to public health purposes and other needs, such as education and housing [42]. There is currently limited literature on these business practices as a separate object of inquiry.

Corporations also use market practices such as product research and development; pricing; marketing, including advertising and retail distribution [1, 15, 25]. There is, for example, ample evidence that the marketing of unhealthy commodities to children and adolescents leads to the increased consumption of these commodities, with associated negative impacts on health [43-45]. Research protocols to systematically study some of these market practices were developed by INFORMAS (International Network for Food and Obesity/non-communicable diseases Research, Monitoring and Action Support) for the food industry [46].

Moreover, corporations use political practices to secure a favourable policy environment [47]. In 2013, Margaret Chan, then Director-General of the World Health Organization, explained: "efforts to prevent noncommunicable diseases go against the business interests of powerful economic operators. In my view, this is one of the biggest challenges facing health promotion" [48]. The political influence of corporations is also known as 'corporate political activity' (CPA) [47]. The political practices of corporations have been extensively studied, in public health, for the tobacco industry [49-51]. This was facilitated by the access to internal documents in the late 1990s, after litigation against large tobacco transnational companies $[52,53]$. These documents have revealed the many ways through which that industry tried to avoid, weaken and delay the development of tobacco control policies $[49,50,54,55]$. There is growing evidence that other companies in the food $[29,30,56$, 57], alcohol [58-60], gambling [61-63], automobile, and chemicals industries [19, 31, 64], for example, use similar political practices. In public health, these political practices are usually classified into two categories [49]:

- Action-based instrumental strategies:

o Coalition management, for example, when corporations build alliances with third parties, 
including health organisations, the media and communities [49], or use their so-called 'corporate social responsibility' initiatives [65, 66];

- Information management, when corporations try to shape the evidence-base in public health [49]. To that end, they for example commission studies and fund research that would be beneficial to their activities and/or products [49] and/or discredit research that would be supportive of public health policies [49];

- Direct involvement and influence in policy, through their lobbying [49], their provision of financial incentives to policymakers and political parties [49], or their participation in working groups and technical meetings with governments [49], amongst other practices;

- Legal strategies [49];

- Argument-based discursive strategies, where corporations, for example, stress the crucial role that the industry plays in the economy, or promote industry-preferred solutions such as education and voluntary initiatives [49].

It has been argued that corporations not only use these political practices; they often capture different branches of governments [67-69], particularly in market-oriented economies that favour their interests [70]. Some aspects of the Public Health Responsibility Deal in the United Kingdom, a public private initiative that aims to improve public health, have been described in the literature as examples of policy capture [71]. For example, it has been shown that, through the Deal, alcohol industry actors shaped their preferred regulatory regime (co-regulation), while avoiding the introduction of more stringent policies that would have limited harmful alcohol drinking [71].

\section{Corporations and the global drivers of ill-health}

In the literature on $\mathrm{CDoH}$, there is a relatively limited discussion on the global drivers of ill-health, and how these are shaped by, and shaping the practices of corporations [72]. These global drivers indeed influence the business, market, and political practices of corporations, therefore facilitating the manufacture, sale and marketing of unhealthy commodities [1]. Market-driven and neoliberal economies, globalisation, and the development of trade and investment agreements, amongst other factors, have for example contributed to the growing power of corporations in recent decades, but also to the ill-health for the population and planet [22, 41, 72-76]. Transnationals, in particular, control their markets in many countries, some markets being saturated, and others, in low- and middleincome countries, emerging [22, 34, 77-80]. These factors shape the consumption of unhealthy commodities globally. It has also been reported that there is a range of individuals that simultaneously sit on different board of directors of large companies in the alcohol, tobacco, and food industries (among other sectors), thus facilitating the exchange of information between these companies, for an articulated control of markets across the globe [81]. Corporate actors also increasingly shape global health governance, through their philanthropic donations and other interactions with international organisations and governments [82].

\section{Discussion}

The present review provides an overview of $\mathrm{CDoH}$, as discussed in the scientific literature, using Kickbush et al.'s framework as a guiding thread. The review therefore covered i) the production of unhealthy commodities by corporations; ii) the use of business, market and political practices that are harmful to health; and iii) global drivers of ill-health, shaped by and shaping the practices of corporations. These different aspects of $\mathrm{CDoH}$ have led to an industrial epidemic. Figure 1 presents these different components of $\mathrm{CDoH}$. However, the way these components combine is currently under studied.

Corporations themselves may be affected by $\mathrm{CDoH}$, through the bad health of their workers, which might increase their absence from the workplace. They may also be affected through the bad health of communities in which they operate, which may decrease their purchase power and willingness to buy, and through the damages that they do to the environment, which may affect their business operations, by decreasing their access to natural resources for example.

An exhaustive review of the literature for each of these aspects of $\mathrm{CDoH}$ was beyond the scope of the present article. This could be the subject of future studies. There is an emerging literature on corporations and the global drivers of ill-health, and this aspect of $\mathrm{CDoH}$ could be studied in future research projects. In addition, the notion of power in relation to $\mathrm{CDoH}$ could be further explored. There is, in parallel, a need for more research on the synergies between these different aspects of $\mathrm{CDoH}$, as stressed by Maani et al. [14]. The models developed by Madureira Lima and Galea [12] and Baum and al [13]. could be used for such purposes. Scholars should continue studying each these different aspects of $\mathrm{CDoH}$ as drivers of ill-health. Baum et al. proposed a research agenda in this respect [83]. More specifically, McCambridge et al. developed a research agenda for studying the political practices of the alcohol industry, which could be applied across different industries [84]. There is also a need for better synergies in understanding and addressing $\mathrm{CDoH}$ not only as drivers of bad health for the population, but also for our planet [76], and as drivers of health and social inequalities. The recent work of the 


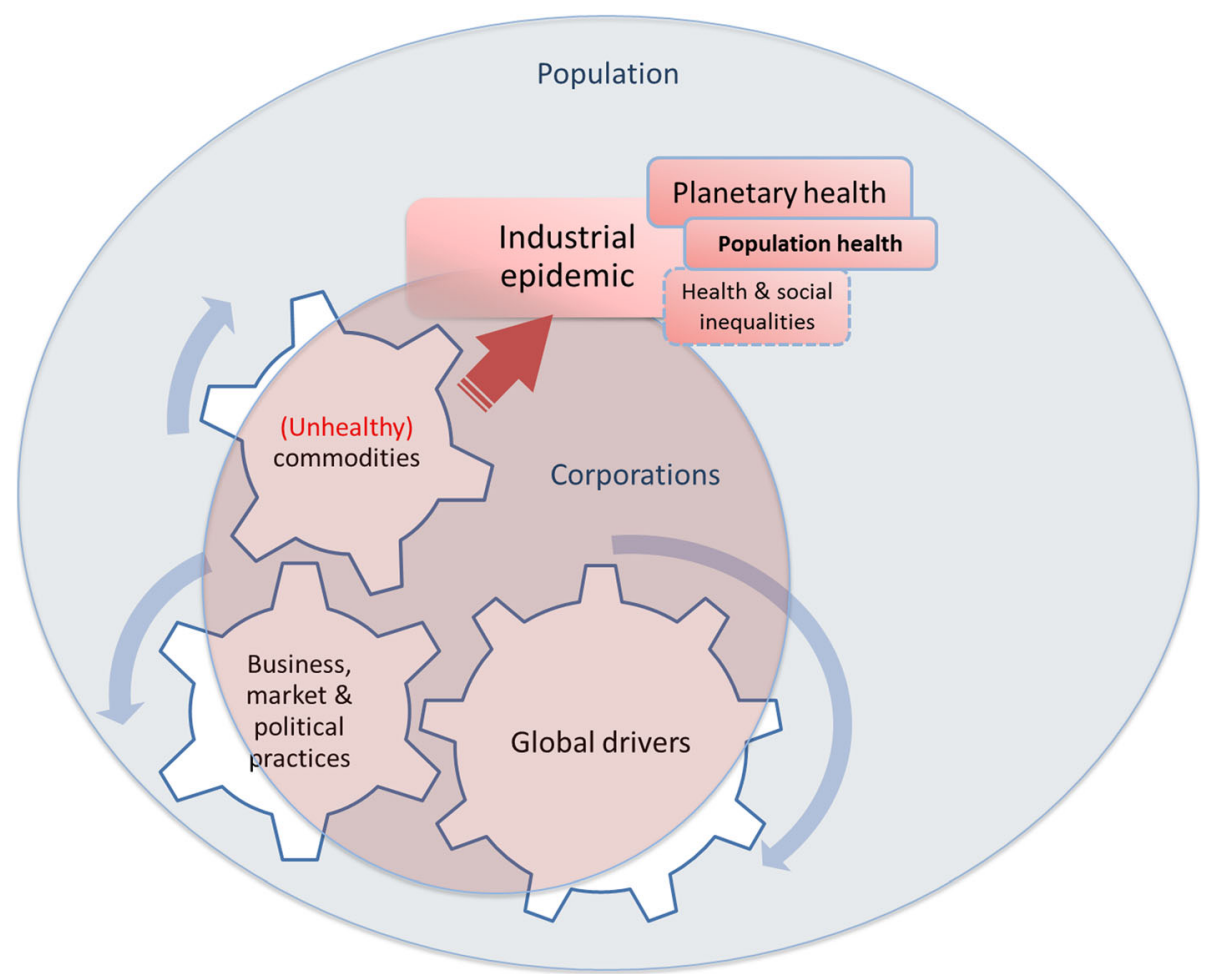

Fig. 1 The commercial determinants of health, as discussed in the scientific literature

Lancet Commission on the "Global Syndemic of Obesity, Undernutrition and Climate Change" is a step in the right direction, with the questions of power imbalance and corporate practices directly addressed [85]. More research is needed to better evaluate both the negative impacts that corporations have on our health, as described in this review, and the positive impacts their activities have $[5,6]$.

Finally, scholars recently proposed solutions to address $\mathrm{CDoH}$ : challenging corporate power and supporting communities who stand up against harmful corporate practices; introducing regulation that would limit these harmful practices; challenging the corporate narrative in public health [2]. There is currently a need for more research on these solutions. West and Marteau concluded in their commentary on $\mathrm{CDoH}$, in 2013, that "re-thinking macro-economics to achieve prosperity without growth [is] a brave but vital initiative to curb the commercial determinants of health before the planet becomes too hostile to support human existence" [8]. Documenting and learning from successful examples in challenging corporations could be important but addressing the global drivers of ill-health might have more impact if $\mathrm{CDoH}$ are to be addressed $[15,76]$.

\section{Conclusion}

There is currently limited research on $\mathrm{CDoH}$ as a separate object of study and a lack of attention, in particular, to the global drivers of ill-health. There is also limited research on the activities of industries other than the food, alcohol and tobacco industries. The discussion on $\mathrm{CDoH}$ offers a unique opportunity to shift the dominant paradigm in public health, where individual behaviours are considered to be driven by inadequate environments. Ill-health, damages to the environment, and health and social inequalities, could rather be understood as shaped by $\mathrm{CDoH}$.

\section{Acknowledgements}

The author would like to acknowledge Eric Crosbie for having proofread a revised version of this manuscript.

\section{Author's contributions \\ The author(s) read and approved the final manuscript.}

\section{Funding}

The current review was adapted from a background section prepared by the author, for a report of the Pan American Health Organization - PAHO/ office of the Americas for the World Health Organization (WHO) in Brazil. PAHO had no role in the preparation of the manuscript. The author is solely responsible for the opinions, hypotheses and conclusions or recommendations expressed in this publication.

\section{Availability of data and materials}

All data generated or analysed during this study are included in this published article.

Ethics approval and consent to participate Not applicable. 


\section{Consent for publication}

Not applicable.

\section{Competing interests}

The author declares that she has no competing interests.

\section{Received: 25 March 2020 Accepted: 5 August 2020}

Published online: 17 August 2020

\section{References}

1. Kickbusch I, Allen L, Franz C. The commercial determinants of health. Lancet Glob Health. 2016:4(12):e895-6.

2. McKee $M$, Stuckler D. Revisiting the corporate and commercial determinants of health. Am J Public Health. 2018;108(9):1167-70.

3. WHO Global Coordination Mechanism on the Prevention and Control of NCDs. GCM/NCD launches new Community of Practice on NCDs and Commercial Determinants of Health. 2018 [cited 2019 Dec 24]. Available from: https://www.who.int/global-coordination-mechanism/news/launchnew-community-of-practice-on-NCDs-and-determinants/en/.

4. Maani N, Collin J, Friel S, Gilmore AB, McCambridge J, Robertson L, et al. Bringing the commercial determinants of health out of the shadows: a review of how the commercial determinants are represented in conceptual frameworks. Eur J Pub Health. 2020. (Published online ahead of print).

5. Millar JS. The corporate determinants of health: how big business affects our health, and the need for government action! Can J Public Health. 2013; 104(4):e327-9.

6. Rochford C, Tenneti N, Moodie R. Reframing the impact of business on health: the interface of corporate, commercial, political and social determinants of health. BMJ Glob Health. 2019;4(4):e001510.

7. Wiist WH. The bottom line or public health : tactics corporations use to influence health and health policy and what we can do to counter them. Oxford. New York: Oxford University Press; 2010.

8. West R, Marteau T. Commentary on Casswell (2013): the commercial determinants of health. Addiction. 2013;108(4):686-7.

9. Hastings G. Why corporate power is a public health priority. BMJ. 2012;345: e5124.

10. Buse K, Tanaka S, Hawkes S. Healthy people and healthy profits? Elaborating a conceptual framework for governing the commercial determinants of non-communicable diseases and identifying options for reducing risk exposure. Glob Health. 2017:13(1):34.

11. World Obesity Federation. Commercial determinants of obesity. [cited 2019 Dec 20]. Available from: https://www.worldobesity.org/what-we-do/ourpolicy-priorities/commercial-determinants-of-obesity.

12. Madureira Lima J, Galea S. Corporate practices and health: a framework and mechanisms. Glob Health. 2018;14(1):21.

13. Baum FE, Sanders DM, Fisher M, Anaf J, Freudenberg N, Friel S, et al. Assessing the health impact of transnational corporations: its importance and a framework. Glob Health. 2016;12(1):27.

14. Maani N, McKee M, Petticrew M, Galea S. Corporate practices and the health of populations: a research and translational agenda. Lancet Public Health. 2020;5(2):e80-1.

15. Freudenberg N. Lethal but legal : corporations, consumption, and protecting public health. USA: Oxford University Press; 2014

16. World Health Organization. Global Health estimates 2016: deaths by cause, age, sex, by country and by region, 2000-2016. Geneva, Switzerland: World Health Organization; 2018.

17. World Health Organization. Noncommunicable diseases country profiles 2018. Geneva, Switzerland: World Health Organization; 2018.

18. Monforton C. Weight of the evidence or wait for the evidence? Protecting underground miners from diesel particulate matter. Am J Public Health. 2006;96(2):271-6.

19. Michaels D. Doubt is their product : how industry's assault on science threatens your health. Oxford. New York: Oxford University Press; 2008.

20. Douglas MJ, Watkins SJ, Gorman DR, Higgins M. Are cars the new tobacco? J Public Health. 2011:33(2):160-9.

21. Brezis M. Big pharma and health care: unsolvable conflict of interests between private enterprise and public health. Isr J Psychiatry Relat Sci. 2008; 45(2):83-9 discussion 90.

22. Stuckler D, McKee M, Ebrahim S, Basu S. Manufacturing epidemics: the role of global producers in increased consumption of unhealthy commodities including processed foods, alcohol, and tobacco. PLoS Med. 2012;9(6): e1001235.

23. Jahiel Rl, Babor T. Industrial epidemics, public health advocacy and the alcohol industry: lessons from other fields. Addiction. 2007;102(9):1335-9.

24. Jahiel RI. Corporation-induced diseases, upstream epidemiologic surveillance, and urban health. J Urban Health. 2008:85(4):517-31.

25. Collin J, Hill S. Industrial epidemics and inequalities: The commercial sector as a structural driver of inequalities in non-communicable diseases. In: Smith KE, Bambra C, Hill SE, editors. Health inequalities: critical perspectives. Oxford: Oxford University Press; 2015. p. 177-91.

26. Knai C, Petticrew M, Mays N, Capewell S, Cassidy R, Cummins S, et al. Systems thinking as a framework for analyzing commercial determinants of health. Milbank Q. 2018;96(3):472-98.

27. Moodie AR. Big alcohol: the vector of an industrial epidemic. Addiction. 2014;109(4):525-6.

28. Bond LD, Chikritzhs T. Selling addictions: similarities in approaches between big tobacco and big booze. Australasian Med J. 2010;3:325-32.

29. Brownell KD, Warner KE. The perils of ignoring history: big tobacco played dirty and millions died. How similar is big food? Milbank Q. 2009;87(1):259-94.

30. Stuckler D, Nestle M. Big food, food systems, and global health. PLoS Med. 2012;9(6):e1001242.

31. MacLennan CA. From accident to crash: the auto industry and the politics of injury. Med Anthropol Q. 1988;2(3):233-50.

32. Freudenberg N, Galea S. The impact of corporate practices on health: implications for health policy. J Public Health Policy. 2008;29(1):86-104 discussion 105.

33. Gilmore AB, Savell E, Collin J. Public health, corporations and the new responsibility Deal: promoting partnerships with vectors of disease? J Public Health. 2011;33(1):2-4.

34. Moodie R, Stuckler D, Monteiro C, Sheron N, Neal B, Thamarangsi T, et al. Profits and pandemics: prevention of harmful effects of tobacco, alcohol, and ultra-processed food and drink industries. Lancet. 2013;381(9867):670-9.

35. Adams PJ. Assessing whether to receive funding support from tobacco, alcohol, gambling and other dangerous consumption industries. Addiction. 2007;102(7):1027-33

36. Reeve B, Gostin LO. Big food, tobacco, and alcohol: reducing industry influence on noncommunicable disease prevention laws and policies comment on "addressing ncds: challenges from industry market promotion and interferences". Int J Health Policy Manag. 2019;8(7):450-4.

37. Tangcharoensathien V, Chandrasiri O, Kunpeuk W, Markchang K, Pangkariya N. Addressing ncds: challenges from industry market promotion and interferences. Int J Health Policy Manag. 2019;8(5):256-60.

38. Madureira Lima J, Galea S. The corporate permeation index - a tool to study the macrosocial determinants of non-communicable disease. SSM Popul Health. 2019;7:100361.

39. Anaf J, Baum F, Fisher M, London L. The health impacts of extractive industry transnational corporations: a study of Rio Tinto in Australia and southern Africa. Glob Health. 2019;15(1):13.

40. Anaf J, Baum FE, Fisher M, Harris E, Friel S. Assessing the health impact of transnational corporations: a case study on McDonald's Australia. Glob Health. 2017;13(1):7.

41. Naik Y, Baker P, Ismail SA, Tillmann T, Bash K, Quantz D, et al. Going upstream - an umbrella review of the macroeconomic determinants of health and health inequalities. BMC Public Health. 2019;19(1):1678.

42. Wiist WH. Public health and corporate avoidance of U.S. federal income tax. World Med Health Policy; 2018.

43. Jernigan D, Noel J, Landon J, Thornton N, Lobstein T. Alcohol marketing and youth alcohol consumption: a systematic review of longitudinal studies published since 2008. Addiction. 2017;112(Suppl 1):7-20.

44. Sadeghirad B, Duhaney T, Motaghipisheh S, Campbell NRC, Johnston BC. Influence of unhealthy food and beverage marketing on children's dietary intake and preference: a systematic review and meta-analysis of randomized trials. Obes Rev. 2016;17(10):945-59.

45. Wellman RJ, Sugarman DB, DiFranza JR, Winickoff JP. The extent to which tobacco marketing and tobacco use in films contribute to children's use of tobacco: a meta-analysis. Arch Pediatr Adolesc Med. 2006;160(12):1285-96

46. Swinburn B, Sacks G, Vandevijvere S, Kumanyika S, Lobstein T, Neal B, et al. INFORMAS (international network for food and obesity/non-communicable diseases research, monitoring and action support): overview and key principles. Obes Rev. 2013;14(Suppl 1):1-12. 
47. Hillman AJ, Keim GD, Schuler D. Corporate political activity: a review and research agenda. J Manage. 2004;30(6):837-57.

48. World Health Organization. Opening address at the 8th Global Conference on Health Promotion Helsinki, Finland - Dr Margaret Chan Director-Genera of the World Health Organization. 2013;

49. Ulucanlar S, Fooks GJ, Gilmore AB. The policy dystopia model: an interpretive analysis of tobacco industry political activity. PLoS Med. 2016; 13(9):e1002125.

50. Gilmore AB, Fooks G, Drope J, Bialous SA, Jackson RR. Exposing and addressing tobacco industry conduct in low-income and middle-income countries. Lancet. 2015;385(9972):1029-43.

51. Savell E, Gilmore AB, Fooks G. How does the tobacco industry attempt to influence marketing regulations? A systematic review. PLoS One. 2014;9(2): e87389.

52. State of California - Department of Justice - Office of the Attorney General. Master SettIment Agreement. 2017. Available from: http://oag.ca.gov/ tobacco/msa.

53. University of California San Francisco. Truth tobacco industry documents. 2017. Available from: https://www.industrydocumentslibrary.ucsf.edu/ tobacco/.

54. World Health Organization. Tobacco industry strategies to undermine tobacco control activities at the World Health Organization. Geneva: World Health Organization; 2000.

55. Saloojee Y, Dagli E. Tobacco industry tactics for resisting public policy on health. Bull World Health Organ. 2000;78(7):902-10.

56. Nestle M. Food politics: how the food industry influences nutrition and health. Berkeley: University of California Press; 2002.

57. Mialon M, Swinburn B, Sacks G. A proposed approach to systematically identify and monitor the corporate political activity of the food industry with respect to public health using publicly available information. Obes Rev. 2015;16(7):519-30.

58. Savell E, Fooks G, Gilmore AB. How does the alcohol industry attempt to influence marketing regulations? A systematic review. Addiction. 2016; 111(1):18-32.

59. McCambridge J, Mialon M, Hawkins B. Alcohol industry involvement in policymaking: a systematic review. Addiction. 2018;113(9):1571-84.

60. McCambridge J, Mialon M. Alcohol industry involvement in science: a systematic review of the perspectives of the alcohol research community. Drug Alcohol Rev. 2018;37(5):565-79.

61. Kypri K, McCambridge J, Robertson N, Martino F, Daube M, Adams P, et al. If someone donates $\$ 1000$, they support you. If they donate $\$ 100000$, they have bought you '. Mixed methods study of tobacco, alcohol and gambling industry donations to Australian political parties. Drug Alcohol Rev. 2019; 38(3):226-33.

62. Hancock L, Ralph N, Martino FP. Applying corporate political activity (CPA) analysis to Australian gambling industry submissions against regulation of television sports betting advertising. PLoS One. 2018;13(10):e0205654.

63. Robertson NM, Sacks G, Miller PG. The revolving door between government and the alcohol, food and gambling industries in Australia. Public Health Res Pract. 2019;29(3):2931921.

64. Lilienfeld DE. The silence: the asbestos industry and early occupational cancer research--a case study. Am J Public Health. 1991;81(6):791-800.

65. Mialon M, Julia C, Hercberg S. The policy dystopia model adapted to the food industry: the example of the Nutri-score saga in France. World Nutr. 2018;9(2):109-20.

66. Fooks G, Gilmore A, Collin J, Holden C, Lee K. The limits of corporate social responsibility: techniques of neutralization, stakeholder management and political CSR. J Bus Ethics. 2013;112(2):283-99.

67. Miller D, Harkins C. Corporate strategy, corporate capture: food and alcohol industry lobbying and public health. Crit Soc Policy. 2010;30(4):564-89.

68. Mindell JS, Reynolds L, Cohen DL, McKee M. All in this together: the corporate capture of public health. BMJ. 2012;345:e8082.

69. Brown T. Legislative capture: a critical consideration in the commercial determinants of public health. J Law Med. 2019;26(4):764-85.

70. Thorn M. Addressing power and politics through action on the commercial determinants of health. Health Promot J Austr. 2018;29(3):225-7.

71. Hawkins B, McCambridge J. Public-private partnerships and the politics of alcohol policy in England: the coalition Government's public health "responsibility Deal". BMC Public Health. 2019;19(1):1477.

72. Stuckler D, Siegel K. Sick societies : responding to the global challenge of chronic disease. Oxford: Oxford University Press; 2011.
73. Rayner G, Hawkes C, Lang T, Bello W. Trade liberalization and the diet transition: a public health response. Health Promot Int. 2006;21(Suppl 1):67-74

74. Hawkes $C$. The role of foreign direct investment in the nutrition transition. Public Health Nutr. 2005:8(4):357-65.

75. ETC Group. Who owns nature? Corporate power and the final frontier in the commodification of life. ETC Group: Ottawa; 2008.

76. Wright C, Nyberg D. Climate change, capitalism, and corporations: processes of creative self-destruction. Cambridge: Cambridge University Press. 2015. p. 243

77. Monteiro CA, Moubarac JC, Cannon G, Ng SW, Popkin B. Ultra-processed products are becoming dominant in the global food system. Obes Rev. 2013;14(Suppl 2):21-8.

78. Lawrence F. Alarm as corporate giants target developing countries. The Guardian; 2011.

79. Swinburn BA, Sacks G, Hall KD, McPherson K, Finegood DT, Moodie ML, et al. The global obesity pandemic: shaped by global drivers and local environments. Lancet. 2011;378(9793):804-14.

80. Friel S, Ponnamperuma S, Schram A, Gleeson D, Kay A, Thow A-M, et al. Shaping the discourse: what has the food industry been lobbying for in the trans Pacific partnership trade agreement and what are the implications for dietary health? Crit Public Health. 2016;26(5):518-29.

81. Collin J, Plotnikova E, Hill S. One unhealthy commodities industry? Understanding links across tobacco, alcohol and ultra-processed food manufacturers and their implications for tobacco control and the SDGS. Tob Induc Dis. 2018;16(1):30.

82. Stuckler D, Basu S, McKee M. Global health philanthropy and institutional relationships: how should conflicts of interest be addressed? PLoS Med. 2011;8(4):e1001020.

83. Baum FE, Margaret AJ. Transnational corporations and health: a research agenda. Int J Health Serv. 2015;45(2):353-62.

84. McCambridge J, Kypri K, Sheldon TA, Madden M, Babor TF. Advancing public health policy making through research on the political strategies of alcohol industry actors. J Public Health. 2019;2020;42(2):262-9.

85. Swinburn BA, Kraak VI, Allender S, Atkins VJ, Baker PI, Bogard JR, et al. The global Syndemic of obesity, Undernutrition, and climate change: the lancet commission report. Lancet. 2019:393(10173):791-846.

\section{Publisher's Note}

Springer Nature remains neutral with regard to jurisdictional claims in published maps and institutional affiliations.
Ready to submit your research? Choose BMC and benefit from:

- fast, convenient online submission

- thorough peer review by experienced researchers in your field

- rapid publication on acceptance

- support for research data, including large and complex data types

- gold Open Access which fosters wider collaboration and increased citations

- maximum visibility for your research: over $100 \mathrm{M}$ website views per year

At $\mathrm{BMC}$, research is always in progress.

Learn more biomedcentral.com/submissions 